\title{
Electrohydrodynamic Preparation of Nanomedicines
}

M. Rasekh ${ }^{1}$, A. Smith ${ }^{1}$, M.S. Arshad ${ }^{2}$, O. Gunduz ${ }^{3}$, S.M. Van der Merwe ${ }^{1}$, G. Smith ${ }^{2}$ and

Z. Ahmad ${ }^{2, *}$.

${ }^{1}$ School of Pharmacy and Biomedical Sciences, University of Portsmouth, St. Michaels Building, White

Swan Road, Portsmouth, PO1 2DT, UK

${ }^{2}$ School of Pharmacy, De Montfort University, Leicester, LE1 9BH, UK

${ }^{3}$ Centre of Nanotechnology \& Biomaterials Application \& Research Centre, Marmara

University, Istanbul, Turkey

*Address correspondence to this author at the School of Pharmacy, De Montfort University, Leicester, LE1 9BH, UK E-mail: zahmad@dmu.ac.uk

\begin{abstract}
The preparation of nanomedicines can be achived using a host of methods ranging from wet-chemical approaches to more engineering related techniques. As a maturing branch of nanotechnology, nanomedcines are being tailored to serve multiple pharmaceutic and biomedical related funcitons (e.g. targeted delivery, imaging, healing, sensing) which may require the utilisaiton of one or more actives or excipients. In some instances, handling of materials (such as sensitive biomolecules or active pharmaceutical ingredient) becomes a limiting factor along with issues related to fabrication steps (loss or degradation of active components and functional materials), deposition location \& procedure (removal of formed structures), process environment sensitivity and scale-up potential. This short review focuses on the electrohydrodynamic preparation of emerging nanomedicines that have potential to serve as therapeutic platforms. An insight into the underpinning process (jet-formation), related paramerts (material and process) and strucutral outcomes (particles and fibres) is given in relation to highlighted research. The ambient temperature processing, user friendly preparation and present industrial scale up potential (now in $\mathrm{kg} / \mathrm{hr}$ ) make such processes valuable in the preparation of future nano-scaled and sensitive dosage forms.
\end{abstract}

Keywords: Electrohydrodynamic, electrospin, electrospray, fibers, nanomedicines, particles.

\section{INTRODUCTION}

Nanomedicine is an evolving branch of nanotechnology that includes the development of nanostructures and nanoanalytical systems to create new diagnostics and therapeutics for medical applications [1]. The utilisation of these materials has led to advances in targeted delivery (drugs to a specific cell or tissue), enhanced delivery of poorly water-soluble drugs, co-delivery of two or more drugs (combination therapy) or even as diagnostic tools [2]. However, the preparation of effective, stable and safe drug delivery systems still represents a significant ongoing challenge in medicine and pharmaceutical sciences [3,4].

Several methods have been developed and adapted in recent times for the preparation of nanoparticles. Such structures (utilising polymers) are prepared from biodegradable and biocompatible materials where the active pharmaceutical ingredient (API) is encapsulated or conjugated with the polymeric matrix system. Common methods of preparation include solvent evaporation [4,5], nanoprecipitation or solvent displacement method [6,7], emulsification [8,9], dialysis [10] and supercritical fluid technology [11,12]. Electrohydrodynamic atomisation (EHDA) techniques (as applied to drug delivery or charged jets resulting in the formation of micrometer and

nanometer scaled architectures. Technological variations to these processes (e.g. by using a variety of processing heads), combined with differences in physical properties of selected and number of liquid (or suspension) phase materials (e.g. formulations) give rise to potential morphological variations [13]. These processes offer a series of advanatges over conventional material and pharmaceutical prepation routes and wil therefore provide several opportunities when coupled to sensitive APIs and biological molecules of significance $[14,15]$. pharmaceutics) are a series of processes driven by electrically charged jets resulting in the formation of micrometer and nanometer scaled architectures. Technological variations to these processes (e.g. by using a variety of processing heads), combined with differences in physical properties of selected and number of liquid (or suspension) phase materials (e.g. formulations) give rise to potential morphological variations [13]. These processes offer a series of advanatges over 
conventional material and pharmaceutical prepation routes and wil therefore provide several opportunities when coupled to sensitive APIs and biological molecules of significance $[14,15]$.

\section{ELECTROHYDRODYNAMIC ATOMISATION (EHDA) PROCESS}

The underlying principle allows the generation of micrometer and nanometer scaled morphologies which are of signifncat interest in the pharmaceutical arena. EHDA is described by Grace and Marijnissen (1994) as tiny droplets obtained from the electrically forced (electro) break-up of a moving (dynamic) liquid (hydro) at a controlled flow rate through a capillary needle fixed at several kilovolts in relation to a ground electrode few centimetres away [16]. The EHDA process is a well-known physical process where a liquid jet breaks up into droplets due to the electric and mechanical forces [17] (Fig. 1). Depending on the magnitiude of the electrical stress, and the kinetic energy of liquid jet leaving the nozzle, a series of spraying modes can be obtained.

In recent years, EHDA methods have developed considerably from the early conceptual experimentations. These exist as electrospraying (particle formation), electrospinning (fibre generation), co-axial generation and direct writing [18-21]. Generation of very fine droplets with near uniform size distribution alongside ambient temperature processing, when compared to other methods, which require very small orifices, are advantages of this process. Rayleigh made the earliest observations on the instability due to the electric charges on drops and jets, and suggested the conditions for a drop or jet to become unstable. The stability of the drop/jet is dependent on the balance of forces, i.e. the outward electrical stresses tending to disrupt the drop and the counteracting surface tension forces trying to hold the drop together [22,23]. Zeleny pioneered the experimental studies of EHDA based on Rayleigh's theories, observed different modes of spraying at the exit of the capillary, which was exposed to an external electric field and was able to produce a qualitative description of the process. This was based on factors such as liquid flow rate from the formulation capillary exit and the applied voltage, and subsequently imaged these different modes [24,25] (common examples shown in Fig. 2). Some of the key benefits of this process are: ambient temperature method (as opposed to melt spinning), scalability (now in $\mathrm{kg} / \mathrm{hr}$ ), multiple parameters enabling morphology variaiton if one is problematic (e.g. increasing the flow rate if the viscosity is too high) and low driving pressure (low flow rates accomodated when compared to pressures required in spray drying).

\section{EHDA CONFIGURATION}

The most typical nomenclature for the spraying heads in EHDA systems is single needle/nozzle or capillary (or often just termed without co-axial). This defines the number of electrically conducting needles/nozzles or capillaries (e.g. stainless steel is generally used) through which media is perfused.

An electric field is applied to the needle (using a voltage supply, typically up to $30 \mathrm{kV}$ or higher if multiple headed devices are being used for scale-up). Media is perfused into the needles using specifically controlled infusion pumps (directly coupled to the processing needle with silicon or other formulation transporting tubing). In addition, the process is varied by the medium in question and its physical properties-especially viscoelastic properties. Under atomising conditions the resulting droplets or fibres (spraying and spinning, respectively) are electrically charged, thus enabling them to be guided and focused easily on to a collecting substrate or directly into a medium, minimising droplet agglomeration (also due to inter-structural charges). Generation of very fine structures with near-uniform size distribution is an advantage of this process. In some processes, a ring or point like ground electrode is placed a few centimetres below the tip of the needle to improve the stability of the jetting mode (Fig. 3 ).

\section{Critical Material Factors}

Both single and coaxial needle atomization processes are able to produce nano-scaled pharmaceutical dosage forms via a single step process, providing control over particle size, size distribution and shape under ambient conditions. The size and size distribution of the particles to be generated could be systematically controlled over a range of operating parameters such as flow rate and applied voltage [26,27]. These can also affect the mode of jetting but when optimised (stable jetting e.g. Taylor cone [28]) EHDA translates into a robust and versatile method for generating advanced drug delivery systems comprising APIs and currently utilised pharmaceutical excipients 
$[29,30,31]$. As well as generating particles with a narrow size distribution by controlling the processing parameters, material (formulation) properties such as density, viscosity, electrical conductivity and surface tension are also crucial elements of the process and will impact structures generated [32,33,34].

Viscosity is a fundamental liquid property, which plays a significant role in the jet break-up process by influencing the hydrodynamic component of the EHDA modes and therefore affects the size of the produced structures [35]. For example, a study found that an increase in viscosity over three orders of magnitude had a dramatic (increasing) effect on the size of particles obtained [36]. Liquid electrical conductivity is the most important property for electrospraying in the stable-jetting mode as it enables jet formation. However, if this is too high, EHDA becomes compromised due to coronal discharge before attaining the required applied voltage for the stable jet mode. Liquids with low conductivity (insulators) cannot be subjected to EHDA alone (e.g., olive oil) although they can be atomised by artificially increasing their electrical conductivities with additives such as ethanol or by combining them with electrically conductive liquids in a coaxial system [35]. The lowest limitation of conductivity is 10-11 Sm-1 [37]. The density of the liquid plays a role in determining the jet diameter of the cone-jet mode. When the viscosity and conductivity of the liquid (formulation) are large enough, the electrical charge is transmitted throughout the jet section by viscous forces. However, the viscous force depends on the density of the liquid [38].

\section{CRITICAL EHDA PROCESSING FACTORS}

Applied voltage is a key variable in establishing the cone-jet (stable jetting) mode and can prevail within a range of values [39]. The electric field between the needle and the ground electrode is a key parameter in controlling the process of EHDA and this is controlled mainly by the applied voltage and the configuration of the ground electrode. A higher applied voltage leads to a stronger atomisation effect on the liquid, thus the atomisation of the liquid takes place mainly due to electrical forces produced by this field. In a specific voltage range, the meniscus of liquid becomes conical and stationary and below this voltage range, the spray always operates in pulsating mode [38].

Every liquid has a minimum flow rate (infusion into the processing nozzle), below which a stable cone-jet mode cannot exist [40]. The droplet size distribution produced using EHDA (in the cone-jet mode) depends on the diameter of the jet and jet break-up into droplets. At this minimum flow rate, the jet breaks up due to varicose instabilities (asymmetrical instabilities). Increasing the flow rate leads to an increase in both current and charge across the liquid cone. Once this is beyond the critical surface charge, lateral instabilities also contribute towards the jet break-up. These are termed kink instabilities and these lead to an increase in the size distribution (broader) of main droplets [40].

\section{STRUCTURAL VARIATIONS WITH EHDA FORMATION}

Advanced materials (materials possessing superior mechanical, chemical properties or those which also have other functional roles e.g. stimulus responsive materials) can be combined together by innovative methods to generate novel or specific active containing materials using EHDA, which is a robust process allowing a more broader range of structures (particles (solid and hollow), layered-fibrous structures and bubbles) $[41,42,43,44]$. This is based on the viscoelastic (fibres (high) to particles (low)) and phase (porosity control based on solvent volatility and degree of solubility) properties of materials, device configuration, flow rates and applied voltage. The resulting structures can also be tailored to fit within a specific size band (e.g. nano or micro scale) based on the concentration of polymer in the solution or the applied voltage during jetting of the formulation (e.g. more viscous solutions can yield larger droplets and fibres in addition to higher voltages resulting in finer structures) [45,46]. In addition to structure size, the surface (roughness, porosity, controlled layering) can also be engineered to achieve a desirable state. Structures can also be formed intermittently (Fig. 4). For example, in electrospinning bead formation [47] can result which is

observed as an intermediate between electrospun and electrosprayed structures. The particle shape can also be controlled by reaching a specific operating voltageflow rate parametric window (aspect ratio variations), which may have further potential in targeted and controlled drug delivery. Advance in shape-related drug delivery is promising.

In-vitro studies have demonstrated enhanced organelle targeting at the cellular level, enhanced antibody specificity and controlled cellular internalisation [48-50] based on shape parameters (aspect-ratio). The opportunity to prepare 
similar structures using EHDA has been demonstrated but in-vitro and in-vivo testing remains to be explored in depth [51].

\section{EHDA PREPARATION OF NANOMEDICINES}

EHDA techniques have been utilised in the preparation of a series of prospective nanomedicines based on the aforementioned underpinning principles and specific material properties. Advances have already been demonstrated in the preparation of nanoparticles and quantum dots [52-55], to deposit ultra-thin films of inorganic, organic and biological materials [56,57], sorting nanoparticles based on their sizes [58] and assisting in the dispersion and delivery of nanomaterials $[59,60]$.

\section{NANOPARTICLES}

EHDA engineered nanoparticles have been adapted for a series of proof of concept studies related to numerous conditions and disease states but are yet to reach the clinic. Some examples of these recent studies are given below.

\section{Chronic Illness Treatment}

The EHDA process can be used to produce polymeric nanoparticles (containing active embedded within a polymeric matrix system) including both hydrophilic and hydrophobic drugs with little adverse impact on the functionality (degradation) of the selected drug. In addition to this benefit, enhanced encapsulation efficacy is also achievable [13, 61].

For example, using a co-axial electrospraying technique (multiple individual material flow to be incorporated into the same nanoparticle architecture) insulin-loaded PLGA (Poly lactic-co-glycolic acid) copolymer nanoparticles have been produced with an encapsulation efficiency of $80+/-4.1 \%$. This process also utilised excipients to retard the burst release of insulin from the PLGA polymer system. One of the key issues with insulin encapsulation is its stability during preparation. However, this was not hindered under one-step EHDA preparation conditions. This single step process yielded $85 \%$ of nanoparticles, which were less than $100 \mathrm{~nm}$ in size [62]. Potential EHDA applications in pulmonary medicine have also been researched. The actives beclomethasone- dipropionate and salbutamol-sulfate have been successfully loaded into an associated biodegradable polymer Polylactide (PLA). In this instance, the average size of particles was $200 \mathrm{~nm}$, which were generated under the stable cone-jet mode [61]. Within the same remit, coaxially aligned needles were optimized to electrospray PLGA particles coated with drugs possessing varying hydrophobicities. The drugs budesonide and EGCG (epigallocatechin gallate) were used and resulting particles demonstrated sizes between $165 \mathrm{~nm}-1.2 \mu \mathrm{m}$ and $158-170 \mathrm{~nm}$, respectively. Budesonide is a class of steroidal hormones (glucocorticoid) to treat asthma and non-infectious rhinitis and it researched in the chemoprevention of lung cancer $[63,64]$.

\section{Cancer Therapeutics}

The ongoing development for the treatment of cancers using advanced novel synthetic products represents one face of product development. An advantage offered by nanoscaled structures provides a gateway to more effective treatment. The anti-cancer drug paclitaxel, in this instance for treating $\mathrm{C} 6$ glioma, demonstrated an encapsulation efficiency of $\sim 80 \%$ [65] when prepared using EHDA. The processes demonstrated the generation of nanometer and micrometer scaled particles, while also focusing on ability to vary their shape and structure (corrugated, doughnut and spherical). Another interesting feature of this study was that an in-vitro release over 30 days was demonstrated. While the structure of particles can be varied, the coating of materials can also be used to target specific sites. For example, in the potential treatment of pancreatic cancer a co-axial needle system has been used in an EHDA set-up to prepare coreshelled folate-chitosan particles with the active gemcitabine [66]. The particle size was 200-300nm and the high encapsulation efficiencies demonstrated remarkable cytotoxicity towards selected cell lines (BXPC3). In addition to these, more coarse $(\sim 500 \mathrm{~nm})$ nanoparticle systems have been developed using EHDA to prepare anticancer therapies involving drugs such as tamoxifen [67].

The anti-cancer drug hydroxycamptothecin has been formulated into acid-liable nanoparticles (based on acid labile segments and galactose components) using the electrospraying technique resulting in particles with a mean size of $230 \mathrm{~nm}$. As was found with several other examples of EHDA fabricated drug-particle systems, the drug-loading efficacy demonstrated a marked improvement when compared to other preparation techniques. In addition, these 
nanoparticles demonstrated prolonged drug release (increased circulation time) making them good candidates for a sustained system. In comparison, they also demonstrate reduced side effects [68].

While drug encapsulation and its efficiency have proven to be an advantageous outcome when using the electrospraying process, researchers have also utilised other features of the nanoscale to enhance drug-delivery and targeting science. For example, directly linked with potential cancer treatment imaging modalities have also been demonstrated on the nanoscale. The co-axial electrospray system provides a route to coat existing nanoparticles as well as preparing multi-coated nanoparticles from pure solutions/mixtures. Iron-oxide (magnetic) nanoparticles with a mean size of $8.2 \mathrm{~nm}$ have been used directly in the formulation medium (oleic acid) for the inner needle of the coaxial device. In this instance, polysorbate 80 was used as the coating material (outer needle). Under EHDA conditions, a multi-layered magnetic nanoparticle system (comprising particle layered with oleic acid, which in turn layered with polysorbate80) was achieved. The mean size of the droplet structures was $96.1 \mathrm{~nm}$. However once deposited into an aqueous phase, the size of these structures was approximately $10.7 \mathrm{~nm}$ with the outer polysorbate80 layer contributing $1.25 \mathrm{~nm}$. The monodisperse nature of these nanoparticles enhanced the MR signal (which is crucial for imaging) and using the same system in a xenograft mouse model the imaging of a tumour site was clearly demonstrated [69]. Based on the multiple layering model demonstrated it is possible to combine other actives and excipients in the preparation of multi-functional nanoparticles.

\section{Gene and Peptide Delivery}

Electrospray can be used to deliver genes into microorganisms. Unlike conventional EHDA particle preparation systems based on a polymer-drug solution, it is possible to use nanoparticles as a colloidal-drug system (or colloidalgene system) to be processed under EHDA conditions. For example, gold nanoparticles (50 nm) were sprayed alongside the plasmid pET30a-GFP directly onto a thin layer of $E$. Coli, which was eventually taken up by these cells [70]. The suggested mechanism by which this occurred was evidenced by electron microscopy of cells. Under the microscope, the appearance of the cellular membrane appears compromised, providing a channel pathway for the entry of plasmid DNA. In contrast, analysis of the sprayed DNA shows this to be intact and unchanged. This method proved to be less destructive compared to other electrical methods used to generate pores in cells for internal delivery of biological molecules [71]. In comparison to several controls, the role of gold nanoparticles demonstrated a clear increase in activity. Although this demonstrated a different approach in electrospray encapsulation and delivery, the potential to use this technique in nanoparticle-assisted cell entry (via EHDA) exists (however several other factors need to be considered such as collecting medium) [70]. Electrospraying has also been used to generate bio-responsive polymer-peptides (genetically engineered elastin like polypeptides), with key emphasis on particle size variations $(300-400 \mathrm{~nm}$ ) based on the various parameters mentioned previously [72].

\section{Emerging Chemistries- Nanotubes}

Current studies into carbon nanotubes have shown their potential emerging scientific applications across a wide remit [73]. The electrospray process has been adapted to prepare these structures in aerosol format with a potential view to utilise these in animal models [74]. Furthermore, decorated nanotubes [75] are a potential route for drug delivery, these structures can be coated (on the nano-scale) with colloidal systems using the electrospray process in a controlled manner [76]. Biological molecules (e.g DNA) can also be coated [77], suggesting a potential route of preparation via electrospray technology.

\section{NANOFIBRES}

While particles have been the primary focus of nanoscaled materials research, there is growing interest in nanofibres as potential carrier systems for API and biological molecules. Nanofibres present a large surface area (increased interaction). When prepared using the electrospinnng process, these structures can also be used to increase the solubility of poorly soluble APIs (rendering them amorphous) [44]. In addition to these, ambient temperature processing and enhanced topographies are also benefits in regenerative medicine.

\section{DNA Nanofibres}

While many APIs continue to be developed, several researchers are focusing on the use of genetic material as a means of tackling diseases largely driven by our growing understanding in the field. Some of the earliest experiments 
including DNA based electrospinning date as far back as 1997 based on thymus genomic DNA resulting in pure DNA fibres with diameters as small as $30 \mathrm{~nm}$ [78]. Later studies have focused more on the inclusion of polymeric systems alongside these materials to prepare fibres or matrix systems with one focusing on lambda DNA (a medium size E.coli bacteriophage used as a model system for regulated site-specific recombination) spun alongside PEO. These fibres possessed diameters between 100-350 nm with the DNA appearing stretched [79], whereas a later study has shown size variations (50-250 $\mathrm{nm}$ ) based on the same system (PEO and DNA) achieved by altering processing parameters such as flow rate, applied voltage and deposition distance. Such matrix systems have potential in advanced cell culturing related applications (including tissue scaffold engineering).

\section{Biomacromolecules as 3D Matrix Systems}

Electrospinning techniques have been used to prepare scaffolds of fibre-based systems with other biological molecules. Some materials (such as collagen) have been used extensively in this form of matrix preparation as well as various other tissue engineering routes, largely due to their biocompatibilities and resemblance to existing structures in the body. For example collagen extracted from calfskin type (I) has been used to prepare nanofibres with diameters in the region of $\sim 100 \mathrm{~nm}$. Within the same work, the importance of fibre orientation for mechanical property control was also demonstrated [80]. More recently, a comparison of electrospun collagen fibres and their native structures focused on the type of solvent system used to prepare the former. The findings demonstrated variations arising in some segments (folded or unfolded) of the protein based on the solvent system (e.g. fluorinated) which highlights the importance of material and solvent selection [81]. While collagen may be the material of choice, it has also been utilised as a composite material. One such study has combined collagen peptides with chito-oligosaccharides (2:1 ratio respectively) to generate electrospun nanofibres in the range of 50-100nm. These fibres demonstrated enhanced anti-bacterial properties with potential applications in wound care [82]. Numerous other examples of composite fibres based on biomacromolecules exist, with one in particular (gelatinpolycaprolactone $(\mathrm{PCL})$, mean fibre diameter $250 \mathrm{~nm}$ ) coating their surfaces with nano-gold particles (using evaporation with resulting nanocomposite thickness in the range 2-14nm). In-vitro tests using cell lines demonstrated the potential of these fibres in cardiac tissue engineering [83].

\section{API Impregnation into Matrix (Polymeric Network)}

Numerous examples of drug loaded (API) polymeric nanofibers have been established. For example, amphotericin B (an anti-fungal drug, at $1 \mathrm{wt} . \%$ ) has been encapsulated in nanofibres with an average diameter of $100 \mathrm{~nm}$ using a base formulation comprising gelatin/acetic acid/water [84]. However, the selection of material is not limited to pure polymeric base systems. Ultra-thin nano-fibres

with high drug loading ability and diameter below $100 \mathrm{~nm}$ were generated using mesoporous materials (TS-1 zeolite). Unlike conventional pure polymer matrix systems, this system was capable of drug loading and release based on the superabsorbent nature of the fibres prepared coupled with the electrostatic properties arising from the metallic ions of TS-1 [85]. In addition to this, these fibres were also able to demonstrate prolonged release of drug, which is an area of ongoing interest in pharmaceutical technologies. Some fibrous structures can also exist in a variety of dosage formats. For example, nanofibres based patches can be developed based on multiple phases (solid or liquids) enabling alterations or control on the release mechanism of actives. As the multiple phases exist, it also permits controlled multiple drug loading and release [86]. There is ample work in various segments of the electrospinning process in relation to active encapsulation, including focus on active type, matrix system and device used to prepare nanofibre systems [13]. Although the vast majority of these systems seem simple (diffusion based release) the focus is to utilise versatile excipients or additional smart material components of the fibre so the release of actives is driven by external triggers. One such preparation has shown the sharp controlled release of dextran from relatively coarse $(600-700 \mathrm{~nm}$ ) nanofibre systems (formulated with copolymers of $N$-isopropylacrylamide and $\mathrm{N}$-hydroxymethylacrylamide) based on temperature responsive mechanisms [87].

\section{Bioactive Ceramics}

Due to advances in science and adequate healthcare, there is an increase in age longevity, which also results in more orthopaedic related complications (natural ageing). An increase in demand for implantable devices has also led to an increase within this area. Ceramic bioactive and biocompatible materials (e.g. hydroxyapatite (HA) and silica possessing specific crystal phases and surface chemistry) coupled to unravelling of cell-topographical (roughness, 
size and chemistry) interactions have led to several explorations using electrospun and electrosprayed systems utilising silica and application related nano-scaled materials $[88,89]$. Titania is used as a biocompatible surface for titanium implants, and silica is considered to have good biological performance. Using electrospinning (followed by heat treatment), nanoscaled titania based ceramic fibres $(100-300 \mathrm{~nm})$ have been prepared. The morphologies and resulting crystal phases of these fibres can be varied based on the initial polymer concentration [90]. One such material considered the gold standard is hydroxyapatite ( $\mathrm{HA})$, and is often utilised as ceramic nanoparticles or as a composite material due to poor mechanical properties. Electrospun fibres make use of these nano-features $(<100 \mathrm{~nm})$ and can be used (along with the fibrous matrix) for enhanced cellular growth [91]. In most studies the focus has centred on the inclusion (physically mixed) of a bioactive material (like nano-scaled HA) to serve a functional role. It is also possible, however, to chemically link nanoceramics to polymeric fibres by utilising a covalently coupled nHA-polymer (e.g. polyurethane) processing solution [92]. Electrospinning has also been used to prepare HA nanoparticles from coarser sizes (from 1440 to $<100 \mathrm{~nm}$ in size) [93]. Finally, while the chemical and nano-features of bioactive materials like $\mathrm{HA}$ are accommodated within the polymeric matrix, multi-active fibres can also be prepared to enhance the biocompatibility of implantable devices e.g. also release actives to prevent or control resulting infections [44].

\section{SUMMARY}

A summary of key EHDA engineered fibre and particle systems is summarised in Table 1.

\section{CONCLUDING REMARKS}

Various EHDA methods and techniques based on the underlying principles have delivered structures with potential applications as nanomedicines. The scaling up of such fabrication routes has shown to be possible and able to produce commercially viable quantities. Coupled to this, ambient condition processing and minimal damage to selected materials (including APIs and cells) provides numerous options in the ongoing development of future medicines. The current status of nanomedicines prepared via EHDA engineering is still at the interface of emerging and exploratory science. Numerous successful animal and in-vitro models have been demonstrated. In addition, from a commercial materials viewpoint, the scalable potential has been proven, potentially enabling the mass scale production of nanomedicines that are proven to be effective in future clinical trials.

Table 1. A summary of selected EHDA engineered nanomedcines.

\begin{tabular}{|c|c|c|c|c|c|c|c|}
\hline Drug/API/ Molecule & $\begin{array}{l}\text { Polymer/ } \\
\text { Matrix }\end{array}$ & Morphology & Size & $\begin{array}{l}\text { In-vitro/In- } \\
\text { vivo } \\
\text { Models }\end{array}$ & Process & Outcome/Notes & Ref. \\
\hline Insulin & PLGA & Particulate & $100 \mathrm{~nm}$ & $\begin{array}{c}\text { In-vitro release } \\
\text { using SBF }\end{array}$ & Co-axial spray & $\begin{array}{c}\text { Encapsulation of insulin and } \\
\text { excipients into biodegradable } \\
\text { nanoparticles at } ~ 80 \% \\
\text { efficiency using a co-axial } \\
\text { system. Release of insulin can } \\
\text { be controlled using excipient }\end{array}$ & 62 \\
\hline $\begin{array}{l}\text { Budesonide and } \\
\text { epigallocatechin } \\
\text { gallate }\end{array}$ & PLGA & Particulate & $\begin{array}{c}160 \mathrm{~nm}-1.2 \\
\mu \mathrm{m}\end{array}$ & $\begin{array}{c}\text { In-vitro release } \\
\text { using PBS }\end{array}$ & Co-axial spray & $\begin{array}{c}\text { Encapsulation of budesonide } \\
\text { and epigallocatechin gallate } \\
\text { and excipients into } \\
\text { biodegradable particles at } ~ 90- \\
95 \% \text { and } 88-92 \% \text { efficiency } \\
\text { respectively }\end{array}$ & 63 \\
\hline $\begin{array}{l}\text { Beclomethasone- } \\
\text { dipropionate and } \\
\text { salbutamol- sulfate }\end{array}$ & PLA & Particulate & $200 \mathrm{~nm}$ & - & $\begin{array}{l}\text { Co-axial spray } \\
\text { but outer } \\
\text { needle is gas }\end{array}$ & $\begin{array}{c}\text { Nitrogen gas fed around the } \\
\text { capillary exit to enhance the } \\
\text { evaporation rate of solvent. } \\
\text { The modified process achieved } \\
\text { be- tween } 54-56 \%\end{array}$ & 61 \\
\hline
\end{tabular}




\begin{tabular}{|c|c|c|c|c|c|c|c|}
\hline Paclitaxel & PCL/PLGA & Particulate & $300 \mathrm{~nm}-15 \mu \mathrm{m}$ & $\begin{array}{c}\text { In-vitro release } \\
\text { using PBS }\end{array}$ & Single spray & $\begin{array}{c}\text { Encapsulation of paclitaxel and } \\
\text { excipients into biodegradable } \\
\text { nano- and micro- particles at }\end{array}$ & 65 \\
\hline Gemcitabine & $\begin{array}{l}\text { Folate- } \\
\text { chitosan }\end{array}$ & Particulate & 200-300nm & $\begin{array}{c}\text { Various } \mathrm{pH} \\
\text { envi- ronments } \\
\text { for re- lease } \\
\text { pro- }\end{array}$ & Co-axial spray & $\begin{array}{c}\text { Encapsulation of gemcitabine } \\
\text { and excipients (folate } \\
\text { conjugated) into } \\
\text { biodegradable core shell } \\
\text { nanoparticles with } \\
\text { encapsulation up to } \sim 85 \% \text { with }\end{array}$ & 66 \\
\hline Tamoxifen & PAA-chol & Particulate & $500 \mathrm{~nm}$ & multicompart & Single spray & $\begin{array}{l}\text { Encapsulation of tamoxifen } \\
\text { with drug loading of about } \\
40 \% \mathrm{w} / \mathrm{w} \text { and the }\end{array}$ & 67 \\
\hline $\begin{array}{l}\text { Hydroxycamp- } \\
\text { tothecin (HCPT) }\end{array}$ & PGBELA & Particulate & $230 \mathrm{~nm}$ & $\begin{array}{c}\text { In-vitro release } \\
\text { using PBS } \\
\text { In-vivo model } \\
\text { using } \\
\text { intravenous }\end{array}$ & Single spray & $\begin{array}{l}\text { HCPT entrapped into PGBELA } \\
\text { at } \sim 80 \% \text { efficiency and } \\
\text { extended release of HCPT. A } \\
\text { superior in vivo antitumor }\end{array}$ & 68 \\
\hline Plasmid DNA & $\begin{array}{c}- \\
\text { (Au } \\
\text { particle) }\end{array}$ & Particulate & $50 \mathrm{~nm}$ & E. Coli & Single spray & \begin{tabular}{|} 
Charged droplets of AU- \\
Plasmid DNA deposited \\
directly on to cells and uptake \\
optimised using buffer \\
solutions. The role of metallic \\
nanoparticles enhanced the \\
plasmid transformation by up \\
to $\sim 7$ fold. Plasmid not \\
changed during the process
\end{tabular} & 70 \\
\hline Doxorubicin & $\begin{array}{c}\text { elastin-like } \\
\text { polypeptid } \\
\text { es (ELP) }\end{array}$ & Particulate & $300-400 \mathrm{~nm}$ & $\begin{array}{c}\text { In-vitro release } \\
\mathrm{pH} \text { - mediated }\end{array}$ & Single spray & $\begin{array}{l}\text { Molecular weight of ELP and } \\
\text { the concentration of solution } \\
\text { play an important role in } \\
\text { morphologies of ELP particles. } \\
\text { Non spherical structures } \\
\text { resulted with low voltages and } \\
\text { high flow rates (tailed } \\
\text { structures). pH dependent } \\
\text { solubility of ELP particles ob- } \\
\text { served. }\end{array}$ & 72 \\
\hline
\end{tabular}

(Table 1) contd....

\begin{tabular}{|c|c|c|c|c|c|c|}
\hline $\begin{array}{c}\text { Drug/API/ } \\
\text { Molecule }\end{array}$ & $\begin{array}{c}\text { Polymer/ } \\
\text { Matrix }\end{array}$ & Morphology & Size & Models & Process & Outcome/Notes \\
\hline Lambda DNA & $\begin{array}{c}\text { Polyethylene } \\
\text { oxide (PEO) }\end{array}$ & Fibres & 100-350nm & - Ref. & $\begin{array}{c}\text { PEO Nanofibers containing } \\
\text { isolated stretched DNA mole- } \\
\text { cules produced. This technique } \\
\text { opens up possibilities in novel } \\
\text { sequencing techniques and } \\
\text { char- acterization of elastic } \\
\text { properties of sections of DNA }\end{array}$ \\
\hline Fish scale colla- \\
gen peptides
\end{tabular}




\begin{tabular}{|c|c|c|c|c|c|c|c|}
\hline & & $\begin{array}{c}\text { Fibres } \\
\text { containing } \\
\text { gold } \\
\text { nanoparticles }\end{array}$ & $\begin{array}{c}2,4 \text { and } 14 \\
\mathrm{~nm} \text { (embed- } \\
\text { deon } 250 \mathrm{~nm} \\
\text { fibres) }\end{array}$ & $\begin{array}{c}\text { Cardiac cells from } \\
\text { neonatal rats }\end{array}$ & $\begin{array}{l}\text { Electrospinning } \\
\text { single needle }\end{array}$ & $\begin{array}{c}\text { Spun polymeric fibres coated } \\
\text { with gold particles via } \\
\text { evapora- tion process. } \\
\text { Compared to pure fibres, gold } \\
\text { coated samples lead to } \\
\text { increased expression of } \\
\text { cardiac sacromeric actinin. } \\
\text { Greater contraction amplitude } \\
\text { observed with nanoparticle }\end{array}$ & 83 \\
\hline $\begin{array}{l}\text { Cefoxitin (so- } \\
\text { dium salt) }\end{array}$ & $\begin{array}{c}\text { TS1-Zeolite } \\
\text { (mesoporous } \\
\text { material) with } \\
\text { poly(butylenes } \\
\text { succinate) }\end{array}$ & Fibres & $\sim 100 \mathrm{~nm}$ & $\begin{array}{c}\text { Phosphate } \\
\text { buffered saline } \\
\begin{array}{c}\text { L929 Fibroblasts } \\
\text { (mouse) }\end{array} \\
\begin{array}{c}\text { S. aureus and K. } \\
\text { nneumonia }\end{array}\end{array}$ & $\begin{array}{l}\text { Electrospinning } \\
\text { single needle }\end{array}$ & $\begin{array}{c}\text { Fibres containing mesoporous } \\
\text { materials can be used a drug } \\
\text { delivery system. The inclusion } \\
\text { of these materials assists in } \\
\text { antibac- terial activity (99.9 \%) } \\
\text { due to metallic ions. TS1- } \\
\text { Zeolite loaded at } 0.1 \mathrm{wt} \% . \\
\end{array}$ & 85 \\
\hline $\begin{array}{c}\text { Betamethasone } \\
\text { acetate }\end{array}$ & $\begin{array}{c}\text { Polymethyl- } \\
\text { silsesquioxane } \\
\text { and Polylactic- } \\
\text { co-glycolic acid }\end{array}$ & $\begin{array}{c}\text { Fibres con- } \\
\text { taining liquid } \\
\text { and particles }\end{array}$ & $\begin{array}{c}\text { Down to } 50- \\
500 \mathrm{~nm} \text { and } \\
\text { encapsulatio } \\
\mathrm{n} \text { in } 2-3 \mu \mathrm{m} \\
\text { hollow tubes }\end{array}$ & - & $\begin{array}{c}\text { Electrospraying } \\
\text { (single needle) and } \\
\text { Electrospinning Co- } \\
\text { axial }\end{array}$ & $\begin{array}{c}\text { Concept paper on preparation } \\
\text { of PLGA nanoparticles } \\
\text { containing Betamethacone } \\
\text { acetate. These encapsulated } \\
\text { into micron scale hollow tubes } \\
\text { using a liquid filled formulation } \\
\text { in the tubular con- structs. } \\
\text { Incorporation into dress- ings }\end{array}$ & 86 \\
\hline $\begin{array}{l}\text { Hydroxyapatite } \\
(\mathrm{HA}) \text { and Indo- } \\
\text { metha- } \\
\text { cin/Ibuprofen }\end{array}$ & $\begin{array}{l}\text { Polycaprolac- } \\
\text { tone }\end{array}$ & $\begin{array}{c}\text { Fibres with } \\
\text { drug and } \\
\text { bioactive } \\
\text { component } \\
\text { (nano- } \\
\text { particles) }\end{array}$ & $\begin{array}{c}400 \mathrm{~nm}-20 \\
\mu \mathrm{m}\end{array}$ & $\begin{array}{c}\text { PBS } 7.4 \\
\text { and SBF for miner- } \\
\text { alisation studies }\end{array}$ & $\begin{array}{l}\text { Electrospinning } \\
\text { Single needle }\end{array}$ & $\begin{array}{l}\text { Fibres demonstrate multiple } \\
\text { functions. Controlled release } \\
\text { of drugs from the structures } \\
\text { based on fibre size and } \\
\text { minerlisaiton due to the } \\
\text { presence of nHA embedded } \\
\text { within them. Encapsu- lati0on } \\
\text { effeicncy for drugs was } ~ 7- \\
10 \% \text {. Drugs incorporated in an } \\
\text { amorphous state. }\end{array}$ & 44 \\
\hline
\end{tabular}

\begin{tabular}{|c|c|c|c|c|c|c|}
\hline $\begin{array}{c}\text { Drug/API/ } \\
\text { Molecule }\end{array}$ & $\begin{array}{c}\text { Polymer/ } \\
\text { Matrix }\end{array}$ & Morphology & Size & Models & Process & Outcome/Notes \\
\hline $\begin{array}{c}\text { Hydroxyapatite } \\
\text { (HA) }\end{array}$ & $\begin{array}{c}\text { Genipin and } \\
\text { chitosan } \\
\text { bedded with } \\
\text { HA particles }\end{array}$ & Fibres em- & Between 228- Osteoblast like 7F2 \\
cells. & $\begin{array}{c}\text { Electrospinning } \\
\text { Single needle }\end{array}$ & $\begin{array}{c}\text { Cross linking of fibres with } \\
\text { genepin increased their size } \\
\text { but also increased their } \\
\text { mechanical properties } \\
\text { significantly. Matching that of } \\
\text { the natural host environ- } \\
\text { ment. HA increased the os- } \\
\text { teonectin mRNA expression. } \\
\text { The concentration of nHA was } \\
\text { varied (0.8, } 1 \text { and } 2 \%) \text { and } \\
\text { genenin rros linker was wsed }\end{array}$ \\
\hline
\end{tabular}




\begin{tabular}{|c|c|c|c|c|c|c|c|}
\hline $\begin{array}{c}\text { Hydrpxyapatite } \\
\text { (HA) }\end{array}$ & $\begin{array}{c}\text { Polyurethane } \\
\text { (PU) }\end{array}$ & $\begin{array}{c}\text { Fibres cova- } \\
\text { lently bound } \\
\text { to HA }\end{array}$ & 300nm & - & $\begin{array}{l}\text { Electrospinning } \\
\text { Single needle }\end{array}$ & $\begin{array}{c}\text { Chemical linking of nHA to } \\
\text { polymer system as opposed to } \\
\text { general processing utilising a } \\
\text { mixture. A chemically bound } \\
\text { nHA-PU solution was first syn- } \\
\text { thesised and then directly } \\
\text { spun. Mechanical properties of } \\
\text { PU can be adjusted while } \\
\text { bioactive properties of matrix } \\
\text { provided by HA. }\end{array}$ & 92 \\
\hline $\begin{array}{c}\text { Hydroxyapatite } \\
\text { (HA) }\end{array}$ & $\begin{array}{l}\text { Polyvinyl } \\
\text { butyral }\end{array}$ & $\begin{array}{c}\text { Coarse fibres } \\
\text { converted } \\
\text { into nanopar- } \\
\text { ticles }\end{array}$ & $\begin{array}{l}<100 \mathrm{~nm} \\
\text { (resulting } \\
\text { particles) }\end{array}$ & $\begin{array}{l}\text { SBF for mineralisa- } \\
\text { tion of fibres }\end{array}$ & $\begin{array}{l}\text { Electrospinning } \\
\text { Single needle }\end{array}$ & $\begin{array}{c}\text { Polymeric fibres spun as a } \\
\text { com- posite with micron } \\
\text { scaled HA with fibre diameters } \\
\text { of } \sim 1 \mu \mathrm{m} \text {. After calcination (600 } \\
\text { oC) fibres result in nano-scaled } \\
\text { HA (<100nm- } 64 \% \text { of all HA } \\
\text { pre- sent by DLS, while TEM } \\
\text { sug- gests } 90 \% \text { less than } \\
50 \mathrm{~nm}) \text {. The reduced size is } \\
\text { more favourable and this can } \\
\text { achieved by the addition of an } \\
\text { anionic SDS surfactant ( } 96 \% \\
\text { below } 100 \mathrm{~nm}) .\end{array}$ & 93 \\
\hline
\end{tabular}

\section{CONFLICT OF INTEREST}

The authors confirm that this article content has no conflict of interest.

\section{ACKNOWLEDGEMENTS}

The authors would like to acknowledge in part PeReNE (EU-INTERREG) and The Royal Society for their support.

\section{REFERENCES}

[1] Wong, I.Y.; Bhatia, S.N.; Toner, M. Nanotechnology: emerging tools for biology and medicine. Genes Dev., 2013, 27, 2397-2408.

[2] Ferrari, M. Cancer Nanotechnology: Opportunities and Challenges. Nat. Rev. Cancer, 2005, 5, 161-171.

[3] Riehemann, K.; Schneider, S.W.; Luger, T.A.; Godin, B.; Ferrari, M.; and Fuchs, H. Nanomedicine-Challenge and Perspectives. Angew. Chem. Int. Ed. Engl., 2009, 48, 872-97.

[4] Lemoine, D.; Preat, V. Polymeric nanoparticles as delivery system for influenza virus glycoproteins. J. Control. Release., 1998, 54, 15-27.

[5] Song, C.X.; Labhasetwar, V.; Murphy, H.; Qu, X.; Humphrey, WR.; Shebuski. RJ. Formulation and characterization of biodegradable nanoparticles for intravascular local drug delivery. J. Control. Release, 1997, 43,197-212.

[6] Fessi, H.; Puisieux, F.; Devissaguet, JP.; Ammoury, N.; Benita, S. Nanocapsule formation by interfacial deposition following solvent displacement. Int. J. Pharm., 1989, 55, R1- R4.

[7] Barichello, J.M.; Morishita, M.; Takayama, K.; Nagai, T. Encapsulation of hydrophilic and lipophilic drugs in PLGA nanoparticles by the nanoprecipitation method. Drug Dev. Ind. Pharm., 1999, 25, 471-476.

[8] Vargas, A.; Pegaz, B.; Debefve, E.; Konan-Kouakou, Y.; Lange, N.; Ballini, JP. Improved photodynamic activity of porphyrin loaded into nanoparticles: an in vivo evaluation using chick embryos. Int. J. Pharm., 2004, 286, $131-45$.

[9] Perez, C.; Sanchez, A.; Putnam, D.; Ting, D.; Langer, R.; Alonso, MJ. Poly(lactic acid)-poly(ethylene glycol) nanoparticles as new carriers for the delivery of plasmid DNA. J. Control. Release, 2001, 75, 211- 24. 
[10] Chronopoulou, L.; Fratoddi, I.; Palocci, C.; Venditti, I.; Russo, MV. Osmosis based method drives the selfassembly of polymeric chains into micro and nanostructures. Langmuir, 2009, 25,11940-11946.

11] York, P. Strategies for particle design using supercritical fluid technologies. Pharm. Sci. Technol. Today, 1999, 2, 430-40.

[12] Kawashima,Y. Nanoparticulate systems for improved drug delivery. Adv. Drug. Deliv. Rev., 2001, 47,1-2.

[13] Zamani, M.; Prabhakaran, M.P.; Ramakrishna, S. Advances in drug delivery via electrospun and electrosprayed nanomaterials. International Journal of Nanomedicine, 2013, 8, 2997-3017.

[14] Jain, A.; Jain, A.; Gulbake, A.; Shilpi, S.; Hurkat, P.; Jain, SK. Peptide and protein delivery using new drug delivery systems. Crit. Rev. Ther. Drug. Carrier. Syst., 2013, 30, 293-329.

[15] Amaral, A.C.; Felipe, M.S. Nanobiotechnology: an efficient approach to drug delivery of unstable biomolecules. Curr. Protein Pept. Sci., 2013, 14, 588-94.

[16] Grace, J.M. and Marijinissen, J.C. M. A review of liquid atomisation by electrical means. J. Aerosol Sci., 1994, 25, 1005-1019.

[17] Hartman, R. P. A. Electrohydrodynamic Atomization in the Cone-Jet Mode from Physical modelling to Powder Production. PhD thesis, Delft University, Netherlands, 1998.

[18] Ahmad, Z.; Rasekh, M.; Edirisinghe, M. Electrohydrodynamic Direct Writing of Biomedical Polymers and Composites. Macromol. Mater. Eng., 2010, 295, 315-319. [19] Levorson, EJ.; Raman, S.P.; Chennazhi, KP.; Kasper, FK.; Nair, SV.; Mikos, AG. Fabrication and characterization of multiscale electrospun scaffolds for cartilage regeneration. Biomed. Mater., 2013, 8, 014103

[20] Ahmad, Z.; Nangrejo, M.; Rasekh, M.; Stride, E; Edirisinghe, M. Novel Electrically Driven Direct-Writing Methods with Direct Control on in-situ Shape and Encapsulation Polymer Forming. Int. J. Mater. Form., 2013, 6, 281-288

[21] Rasekh, M.; Ahmad, Z.; Day, R.; Edirisinghe, M. Direct Writing of Polycaprolactone Polymer for Potential Biomedical Engineering Applications. Adv Eng Mater: Advanced Biomaterials, 2011, 13, B296-B305

[22] Rayleigh, L. On the capillary phenomena in jets. , Proc. R. Soc. Lond., 1879, 29, 71-97.

[23] Rayleigh, L. On the instability of jets. Proc. R. Soc. Lond. A. Mat., 1878, 10, 4-13.

[24] Zeleny, B. J. The Electrical Discharge from Liquid Points, and a Hydrostatic Method of Measuring the Electric Intensity at Their Surfaces. Phys. Rev., 1914, 3, 69-91.

[25] Zeleny, B. J. Instability of Electrified Liquid Surfaces. Phys. Rev., 1917, 17, 1-6.

[26] Kim, W.; Kim, S.S. Synthesis of biodegradable triple-layered capsules using a triaxial electrospray method, Polymer, 2011, 52, 3325-3336.

[27] Ryan, C.N.; Smith, K.L.; Stark, J.P.W. The influence of geometry on the flow rate sensitivity to applied voltage within cone-jet mode electrospray. J. Appl. Phys., 2012, 112, 114510

[28] Cejkova, J.; Stepanek, F. Compartmentalized and Internally Structured Particles for Drug Delivery. Curr. Pharm. Design, 2013, 19, 6298-6314.

[29] Ho, H.; Lee, J. PEG/PLA core/shell particles from coaxial electrohydrodynamic spray drying. Macromolecular Research, 2011, 19, 815-821.

[30] Ding, L.; Lee, T.; Wang, C. Fabrication of monodisperse Taxol loaded particles using electrohydro dynamic atomization. J. Control. Release, 2005, 102, 395-413.

[31] Rezvanpour, A.; Krantz, W.B.; Wanga, C-H. Scaling analysis of the electrohydrodynamic atomization (EHDA) process for pharmaceutical particle fabrication. Chem. Eng. Sci., 2012, 80, 81- 90. 
[32] Xie, J.; Ng, W.J.; Lee, L.Y.; Wang, C.; Encapsulation of protein drugs in biodegradable microparticles by co-axial electrospray. J. Colloid. Interface Sci., 2008, 317, 469-476.

[33] Ahmad, Z.; Zhang, H.B.; Farook, U.; Edirisinghe, M.; Stride, E.; Colombo, P. Generation of multilayered structures for biomedical applications using a novel tri-needle co-axial device and electrohydrodynamic flow. J R. Soc. Interface, 2008, 27, 1255- 1261.

[34] Lopez-Harrera, J.M.; Barrero, A.; Lopez, A.; Loscertales, I.G.; Marquez, M. Coaxial jets generated from electrified Taylor cones. Scaling laws. J. Aerosol. Sci., 2003, 34, 535-552.

[35] Weber, C. On the breakdown of a fluid jet. J. Mech.Appl. Math., 1931, 11, 136-159.

36] Smith, D. P. H. The Electrohydrodynamic Atomization of Liquids. IEEE T. Ind. Appl., 1986, 22, 527-535.

[37] Ganon-Calvo, A.M. Cone Jet Analytical Extension of Taylor's Electrostatic Solution and the Asymptotic Universal Scaling Laws in Electrospraying. Phys. Rev. Lett., 1997, 79, 217-220.

[38] Tang, K.; Gomez, A. On the structure of an electrostatic spray of monodisperse droplets. Phys. Fluids, 1994, 6, 2317-2332.

[39] Hartman, R.P. A.; Brunner, D. J.; Camelot, D. M. A.; Marijnissen, J.C.M. and Scarlett, B. Jet Break-Up in Electrohydrodynamic Atomization in the Cone-Jet Mode. J. Aerolsol Sci., 2000, 31, 65-95.

[40] Ganan-Calvo, A. M.; Rebollo-Muñoz, N.; Montanero, J. M. The minimum or natural rate of flow and droplet size ejected by Taylor cone-jets: physical symmetries and scaling laws. New Journal of Physics, 2013, 15, 033035

[41] Anumolu, R.; Gustafson, J.A.; Magda, J.J.; Cappello, J.; Ghandehari, H.; Pease, L.F. Fabrication of highly uniform nanoparticles from recombinant silk-elastin-like protein polymers for therapeutic agent delivery. Acs Nano., 2011, 5, 5374-5382.

[42] Mou, F.; Xu, L.; Ma, H.; Guan, J.; Chen, D.R.; Wang, S. Facile preparation of magnetic $\mathrm{\gamma}^{-} \mathrm{Fe}_{2} \mathrm{O}_{3} / \mathrm{TiO}_{2}$ Janus hollow bowls with efficient visible-light photocatalytic activities by asymmetric shrinkage. Nanoscale, 2012, 4, 4650-4657.

[43] Ekemen, Z.; Ahmad, Z.; Stride, E.; Kaplan, D.; Edirisinghe, M. Electrohydrodynamic bubbling: an alternative route to fabricate porous structures of silk fibroin based materials. Biomacromolecules, 2013, 14, 1412-1422.

[44] Karavasili, C.; Bouropoulos, N.; Kontopoulou, I.; Smith, A.; Van der Merwe, S.M.; Ur Rehman, I.; Ahmad, Z.; Fatouros, D.G. Preparation and characterization of multi-active electrospun fibers: Poly- $\varepsilon$-carpolactone fibers loaded with hydroxyapatite and selected NSAIDs. J. Biomed. Mater. Res. A., 2013, doi: 10.1002/jbm.a.34931.

[45] Enayati, M.; Ahmad, Z.; Stride, E.; Edirisinghe, M. Size mapping electric field assisted production of polycaprolactone drug loaded particles. J. R. Soc. Interface, 2010, 7. S393-S404.

[46] Nangrejo, R.; Bernado, E.; Colombo, P.; Farook, U.; Ahmad, Z.; Edirisinghe, M.; Stride, E. Electrohydrodynamic forming of porous ceramic capsules from a preceramic polymer. Mater. Lett., 2009, 63.483-485.

[47] Pham, Q. P.; Sharma, U.; Mikos, A.G. Electrospinning of polymeric nanofibers for tissue engineering applications: A review. Tissue Eng., 2006, 12, 1197-1211.

[48] Champion, J.A.; Mitragotri, S. Role of target geometry in phagocytosis. Proc. Natl. Acad. Sci. USA, 2006, 103, 4930-4934.

[49] Barua, S.; Yoo J.-W.; Kolhar, P.; Wakankar, A.; Gokarn, Y.; Mitragotri S. Particle Shape Enhances Avidity and Specificity of Antibodies. PNAS, 2013,110, 3270-3275.

[50] Kolhar, P.; Mitragotri, S. Size and Shape of Microparticles Impact their Localization around the Nucleus after Endocytosis. Advanced Functional Materials, 2012, 28, 3759-3764.

[51] Enayati, M.; Ahmad, Z.; Stride, E.; Edirisinghe, M., Preparation of Polymeric Carriers for Drug Delivery with Different Shape and Size Using an Electric Jet. Curr. Pharm. Biotechnol.. 2009, 10, 600---608. 
[52] Salata, O.V.; Dobson, P.J.; Hull, P.J.; Hutchison, J.L. Fabrication of PBS Nanoparticles Embedded in a Polymer Film by a Gas-Aerosol Reactive Electrostatic Deposition Technique. Adv. Mater., 1994, 6, 772-775

[53] Hull, P.J.; Hutchison, J.L.; Salata, O.V.; Dobson, P.J. Synthesis of nanometer-scale silver crystallites via a roomtemperature electrostatic spraying process. Adv. Mater., 1997, 9, 413-417.

[54] Lenggoro, I.W.; Okuyama, K.; Fernandez de la Mora, J.; Tohge, N. Preparation of ZnS nanoparticles by electrospray pyrolysis. J. Aerosol Sci., 1999, 31, 121-136.

[55] Chen, C.H.; Kelder, E.M.; vander Put, P.J.; Schoonman, J.M.J. Morphology control of thin LiCoO2 films fabricated using the electrostatic spray deposition (ESD) technique J.Mater. Chem., 1996, 6, 765-771

[56] Thundat, T.; Warmack, R.J.; Allison, D.P.; Ferrel, T.L. Electrostatic spraying of DNA molecules for investigation by scanning tunneling microscopy. Ultramicroscopy, 1992, 42, 1083-1087.

[57] Morozov, V.N.; Morozova, T.Ya. Electrospray deposition as a method to fabricate functionally active protein films. Anal. Chem., 1999, 71, 1415-1420.

[58] Lenggoro, W.I.; Xia, B.; Okuyama, K. Sizing of colloidal nanoparticles by electrospray and differential mobility analyser methods. Langmuir, 2002, 18, 4584-91.

[59] Nakasoa, K.; Hanb, B.; Ahnc, K.H.; Choib, M.; Okuyama, K. Synthesis of non-agglomerated nanoparticles by an electrospray assisted chemical vapor deposition (ES-CVD) method. J. Aerosol Sci., 2003, 34, 869-881.

[60] Signorell, R.; Kunzmann, M.K.; Suhm, M.A. FTIR investigation of non-volatile molecular nanoparticles. Chem. Phys. Lett., 2000, 329, 52-60.

[61] Valo, H.; Peltonen, L.; Vehvilalnen, S.; Karjalainen, M.; Kostiainen, R.; Laaksonen, T.; Hirvonen, J. Electrospray encapsulation of hydrophilic and hydrophobic drugs in poly (llactic acid) nanoparticles. Small, 2009, 5, 1791-1798.

[62] Bakhshi, R.; Ahmad, Z.; Soric, M.; Stride, E.; Edirisinghe, M. Nanoparticle Delivery Systems Formed Using Electrically Sprayed Co-Flowing Excipients and Active Agent. Journal of Biomedical Nanotechnology, 2011, 7, 782793.

[63] Lee, Y.H.; Mei, F.; Bai, M.Y.; Zhao, S.; Chen, D.R. Release profile characteristics of biodegradable-polymer-coated drug particles fabricated by dual-capillary electrospray. J. Control. Release, 2010, 145, 58-65.

[64] Wattenberg, L.W.; Wiedmann, T.S.; Estensen, R.D.; Zimmerman, C.L.; Steele, V.E.; Kellof, G.J. f. Chemoprevention of pulmonary carcinogenesis by aerosolized budesonide in female A/J mice, Cancer Res., 1997, 57, 5489-5492.

[65] Xie, J.; Marijnissen, J.C.M.; Wang, C.H. Microparticles developed by electrohydrodynamic atomization for the local delivery of anticancer drug to treat $\mathrm{C} 6$ glioma in vitro. Biomaterials, 2006, 27, 3321-3332.

[66] Xu, S.; Xu, Q.; Zhou, J.; Wang, J.; Zhang, N.; Zhang, L. Preparation and characterization of folate-chitosangemcitabine core-shell nanoparticles for potential tumor-targeted drug delivery. J. Nanosci. Nanotechnol., 2013, 13, 129-38.

[67] Cavalli, R.; Bisazza, A.; Bussano, R.; Trotta, M.; Civra, A.; Lembo, D.; Ranucci, E.; and Ferruti, P. Poly(amidoamine)- Cholesterol Conjugate Nanoparticles Obtained by Electrospraying as Novel Tamoxifen Delivery System. Journal of Drug Delivery, 2011, 587604

[68] Luo, X.; Jia, G.; Song, H.; Liu, C.; Wu, G.; Li, X. Promoting antitumor activities of hydroxycamptothecin by encapsulation into Acid-labile nanoparticles using electrospraying. Pharm. Res., 2014, 31, 46-59.

[69] Kim, SY.; Yang, J.; Kim, B.; Park, J.; Suh, JS.; Huh, YM.; Haam, S.; Hwang, J. Continuous coaxial electrohydrodynamic atomization system for water-stable wrapping of magnetic nanoparticles. Small, 2013, 9, 232530.

[70] Lee, YH.; Wu, B.; Zhuang, WQ.; Chen, DR.; Tang, YJ. Nanoparticles facilitate gene delivery to microorganisms via an electrospray process. J. Microbiol. Methods, 2011, 84, 228-233. 
[71] Tsong, M.L. Electroporation of cell membranes. Biophys. J., 1991. 60, 297-306.

[72] Wu, Yiquan.; MacKay, J. A.; McDaniel, J.R.; Chilkoti, Ashutosh.; Clark R.L. Fabrication of Elastin-Like Polypeptide Nanoparticles for Drug Delivery by Electrospraying. Biomacromolecules, 2009, 10, 19-24.

[73] Mamalis, A.G.; Vogtländer, L.O.G.; Markopoulos, A. Nanotechnology and nanostructured materials: trends in carbon nanotubes. Precision Engineering, 2004, 28, 16-30.

[74] Jennerjohn, N.; Eiguren-Fernandez, A.; Prikhodko, S.; Fung, D.C.; Hirakawa, K.S.; Zavala-Mendez, J.D.; Hinds, W.; and Kennedy, N. J. Design, demonstration and performance of a versatile electrospray aerosol generator for nanomaterial research and applications. Nanotechnology, 2010, 21, 255603.

[75] Yang, D.; Yang, F.; Hu, J.; Long, J.; Wang, C.; Fu, D.; Ni, Q. Hydrophilic multi-walled carbon nanotubes decorated with magnetite nanoparticles as lymphatic targeted drug delivery vehicles. Chem. Commun. (Camb), 2009, 7, 44474449 .

[76] Mao, S.; Lu, G.; Chen, J. Coating carbon nanotubes with colloidal nanocrystals by combining an electrospray technique with directed assembly using an electrostatic field. Nanotechnology, 2008, 19, 455610.

[77] Staii, C. and Johnson, A. T. Jr. DNA-Decorated Carbon Nanotubes for Chemical Sensing. Nano. Lett., 2005, 5, 1774-1778 [78] Fang, X.; Reneker, D.H. DNA Fibers by Electrospinning. J. Macromol.

Sci. Phys. B, 1997, 36, 169-173. [79] Bellan, L.M.; Cross, J.D.; Strychalski, E.A.; Moran-Mirabal, J.; Craighead, H.G. Individually resolved DNA molecules stretched and embedded in electrospun polymer nanofibers. Nano Lett., 2006, 6, 2526-2530.

[80] Matthews, J.A.; Wnek, G.E.; Simpson, D.G.; Bowlin, G.L. Electrospinning of collagen nanofibers, Biomacromolecules, 2002, 3, 232-238.

[81] Burck, J.; Heissler, S.; Geckle, U.; Ardakani, M.F.; Schneider, R.; Ulrich, A.S.; Kazanci, M. Resemblance of Electrospun Collagen Nanofibers to Their Native Structure. Langmuir, 2013, 29, 1562-72.

[82] Wang, Y.; Zhang, C.U.; Zhang, Q.; Li, P. Composite electrospun nanomembranes of fish scale collagen peptides/chitooligosaccharides: antibacterial properties and potential for wound dressing. International Journal of Nanomedicine, 2011, 6, 667-676.

[83] Shevach, M.; Maoz, B.M.; Feiner, R.; Shapira, A.; Dvir, T. Nanoengineering gold particle composite fibers for cardiac tissue engineering. Journal of Materials Chemistry B, 2013 ,1, 5210- 5217.

[84] Sekhar, N.; Himansu, C.; Mishra, N. Amphotericin B Loaded Natural Biodegradable Nanofibers as a Potential Drug Delivery System against Leishmaniasis. Current Nanoscience, 2011, 7, 943- 949.

[85] Sung, Y.H.; Won, J.Y.; Sung, H.Y.; Eui, S.Y.; Tai, H.K.; Seung, S.I. Fabrication of superabsorbent ultrathin nanofibers using mesoporous materials for antimicrobial drug-delivery applications. Macromolecular Research, 2013, 21, 1281-1288.

[86] Ahmad, Z; Stride, E; Edirisinghe. Novel preparation of transdermal drug-delivery patches and functional wound healing materials. J.Drug Target., 2009, 17, 724-729.

[87] Kim, Y.J.; Ebara, M.; Aoyagi, T. Temperature-responsive electrospun nanofibers for 'on-off' switchable release of dextran. Sci. Technol. Adv. Mater, 2012, 13. 064203

[88] He, H.Y.; Wang, J.; Li, X.; Zhang, X.W.; Weng, W.J.; Han, G.R. Silica nanofibers with controlled mesoporous structure via electrospinning: from random to orientated, Mater. Lett., 2013, 94, 100-103.

[89] Li, X.; Huang, J.; Edirisinghe, M.J.; Bonfield, W. An electrically driven jetting technique for diverse high-resolution surface structures of nanometre hydroxyapatite crystals. Colloid. Surface. B, 2011, 82, 562-570.

[90] Xiaokun, W.; Jingxian, Z.; Ling, Y.; Shize, L.; Xin, Z.;Yingfang, A.; Haifeng C. Evaluation of theMorphology and Osteogenic Potential of Titania-Based Electrospun Nanofibers. Journal of Nanomaterials, 2012, 959578 
[91] Frohbergh, M.E.; Katsman, A.; Botta, G.P.; Lazarovici, S.C.L.P.; Wegst, U.G.K.; Lelkes, P. I. Electrospun hydroxyapatite-containing chitosan nanofibers cross linked with genipin for bone tissue engineering. Biomaterials, 2013, 33, 9167-9178.

[92] Khan, A.; Ahmad, Z.; Edirisinghe, M.; Wong, F. and Rehman, I.Preparation and characterisation of a novel bioactive restorative composite based on covalently coupled polyurethane-nanohydroxyapatite fibres. Acta Biomater., 2008, 4, 1275-1287

[93] Zakaria, S.M.; Zein, S.H.S.; Othman, M.R.; Jansen, J.A. Hydroxyapatite nanoparticles: Electrospinning and calcination of hydroxyapatite/ polyvinyl butyral nanofibers and growth kinetics. J.Biomed. Mater. Res-A, 2013, 101, 1977-1985.

\section{LIST OF FIGURES}

Fig. (1). A diagramatic representation of jet formation showing some of the various forces involved.

Fig. (2). Selected jetting modes showing (a) no flow from needle exit (b) conventional micro-dripping from needle exit (low electricfield/ applied voltage) (c) unstable jetting (approaching near optimal electric field) and (d) stable spraying (optimised applied voltage), [the scale bars are $5 \mathrm{~mm}$ ].

Fig. (3). Basic electrohydrodynamic (EHDA) set-up (the scal bar is $5 \mathrm{~mm}$ ).

Fig. (4). Structural variations due to process and material parameters.

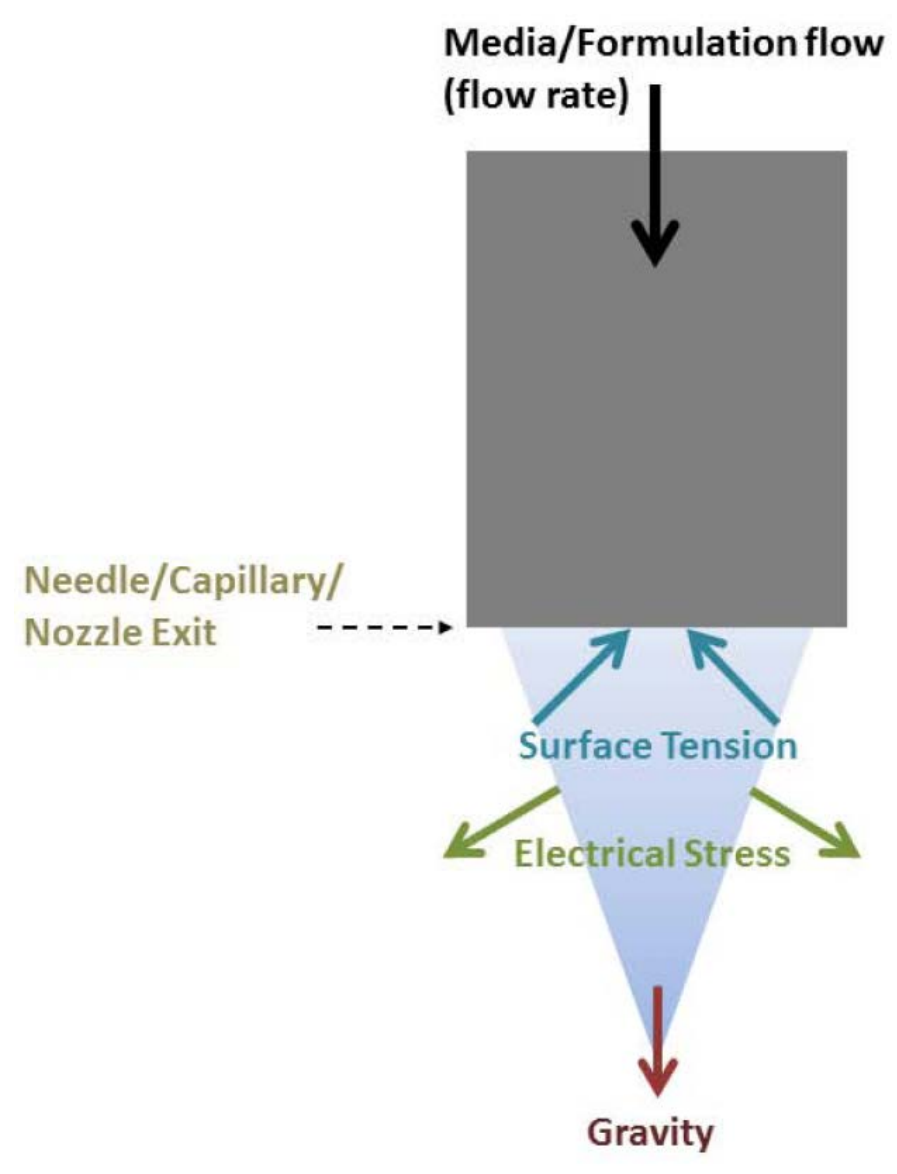

Figure (1) 


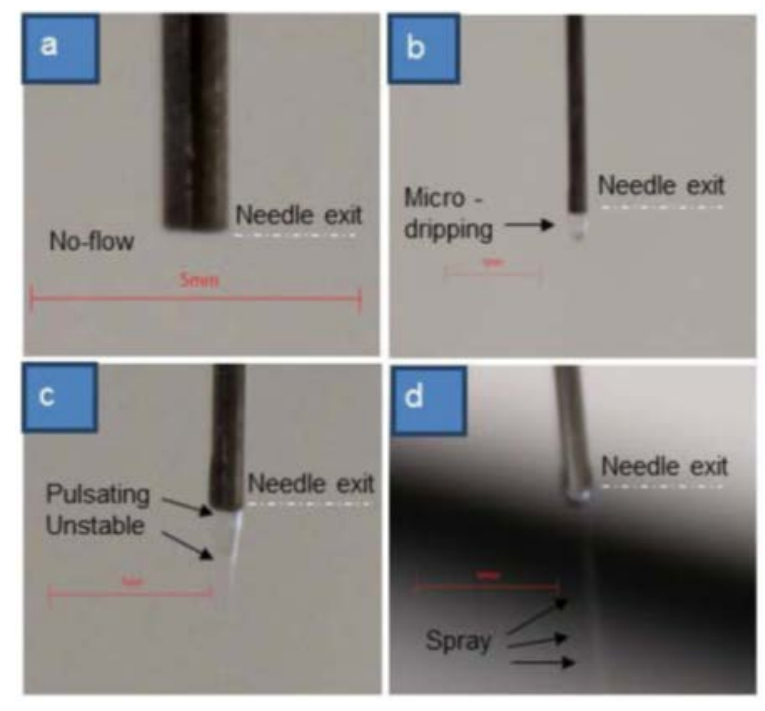

Fig (2).

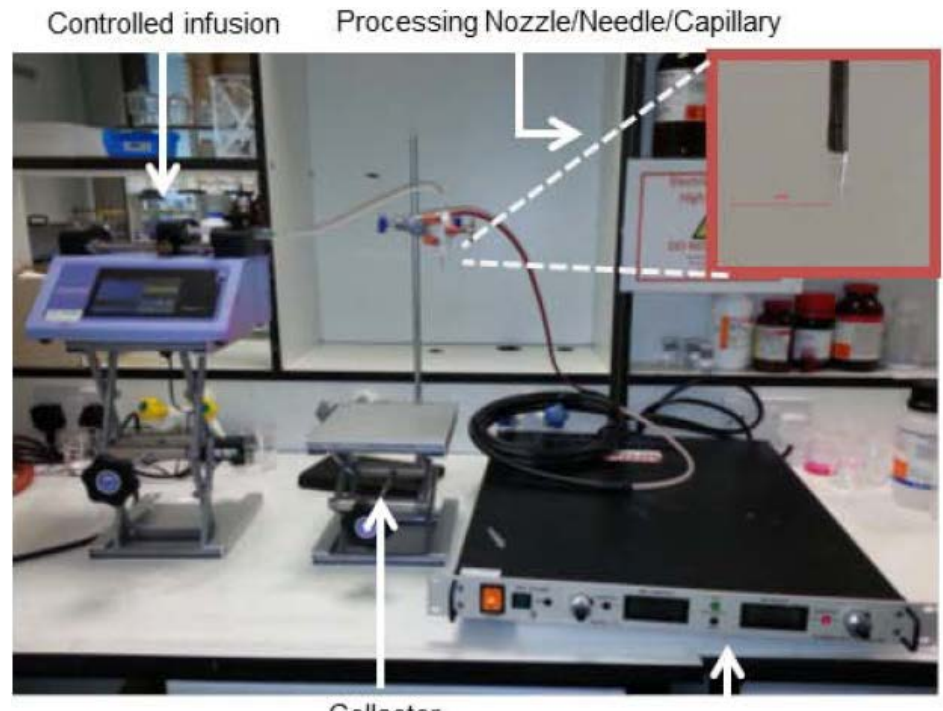

Collector

Voltage source

Fig (3). 


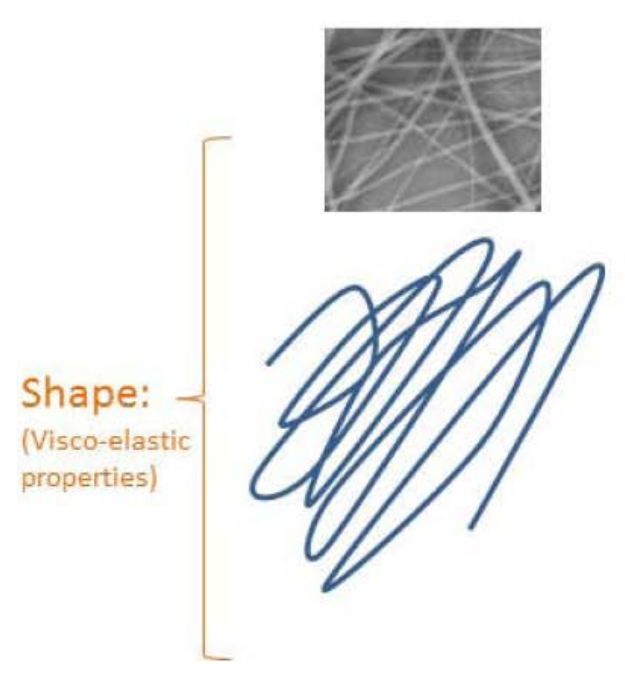

Nano-Fibres

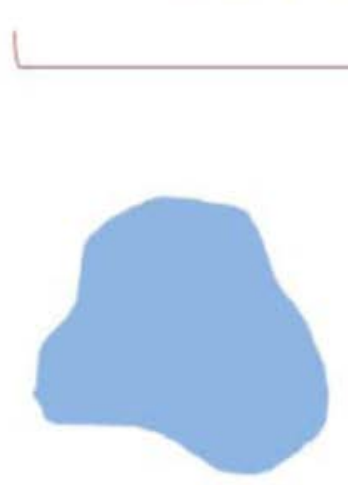

Smooth

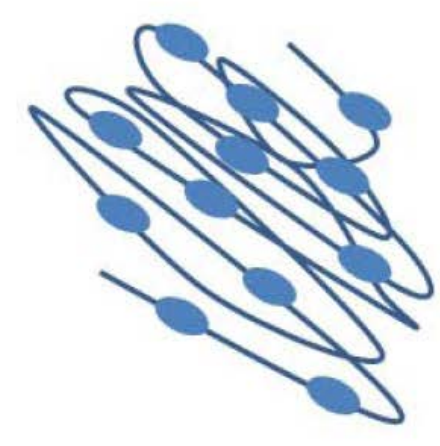

Beaded
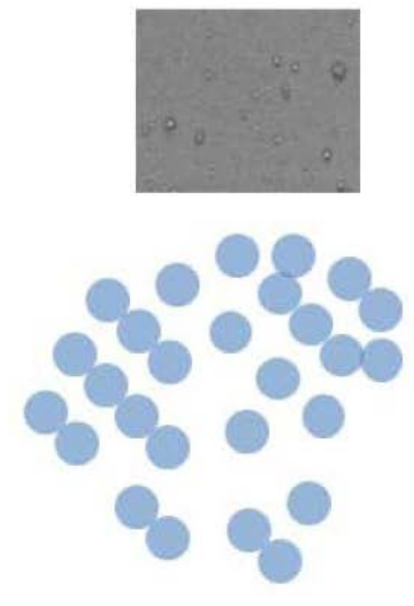

Nano-Particles

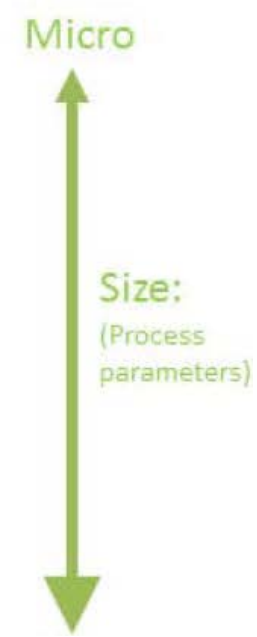

Nano

Surface Morphology:

(Media Properties)

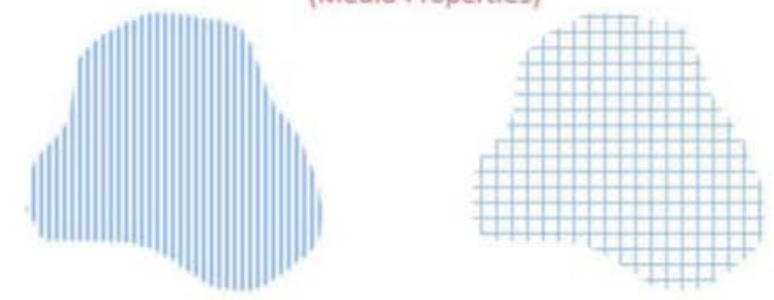

Porous

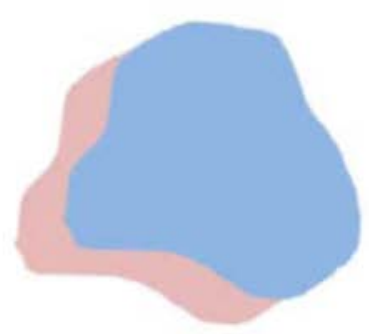

Layered

Fig (4). 